Canadian University Music Review

Revue de musique des universités canadiennes

\title{
Conductus as Analgesic
}

\section{Bryan Gillingham}

\author{
Numéro 14, 1994 \\ URI : https://id.erudit.org/iderudit/1014310ar \\ DOI : https://doi.org/10.7202/1014310ar
}

Aller au sommaire du numéro

\section{Éditeur(s)}

Canadian University Music Society / Société de musique des universités canadiennes

\section{ISSN}

0710-0353 (imprimé)

2291-2436 (numérique)

\section{Découvrir la revue}

\section{Citer cet article}

Gillingham, B. (1994). Conductus as Analgesic. Canadian University Music Review / Revue de musique des universités canadiennes, (14), 49-59.

https://doi.org/10.7202/1014310ar

\section{Résumé de l'article}

One of the difficulties in creating an adequate picture of the contextual situation for music, other than that clearly associated with the liturgy, in the Middle Ages, is the paucity of accounts describing performance circumstances. We know little about the social milieu and purposes attending genres marginal to the liturgy such as the conductus and thirteenth-century motet. A manuscript which seems to redress this problem, albeit for one very specific instance, is Vat. lat. 2854 in the Vatican library in Rome.

This manuscript is unusual in that it contains not only music but a detailed account of why the music was written. The author, Bonaiutus de Casentino, active in the circle of Pope Boniface VIII, prepared the manuscript in the last decade of the thirteenth century at Rome. The document includes various poems, sacred and secular, as well as two Latin songs written in late Franconian notation. One of the pieces is a two-voice conductus (Hec medela corporalis) which was written, according to the account of Bonaiutus himself, in order to cure the maladies of an ailing pontif. The pontifical complaints seemed to be both psychological and intestinal in nature. It was the hope of Bonaiutus not only to provoke laughter (always a curative), but also to cleanse the papal bowels through his composition. Although one cannot generalize on the basis of this single incident, it does yield a fascinating glimpse into a possible venue for the conductus.
All Rights Reserved (C Canadian University Music Society / Société de musique des universités canadiennes, 1994
Ce document est protégé par la loi sur le droit d'auteur. L’utilisation des services d'Érudit (y compris la reproduction) est assujettie à sa politique d'utilisation que vous pouvez consulter en ligne.

https://apropos.erudit.org/fr/usagers/politique-dutilisation/ 


\section{CONDUCTUS AS ANALGESIC}

\section{Bryan Gillingham}

Information about the conductus survives mainly in two distinct types of archival record: theoretical treatises and manuscript anthologies of the music itself. Most contextual features of this common late medieval song type, such as performing forces, liturgical position, patronage, composers, dates, remain enigmatic and even the very definition of the genre is confusing. The few medieval theorists who mention the conductus allude to its inherent musical style usually in a cursory manner, rather than placing the type in its context. In central sources of the conductus such as F (Florence, Pluteus 29.1) the pieces are not labelled "conductus," survive in a variety of forms, focus on different subjects, and are completely devoid of rubrication which might indicate their venue and function. In a repertoire of approximately 260 pieces in $\mathbf{F}$ which could be considered conductus, none of the exemplars are labelled as such and there is no indication whatsoever as to context. We are better served by manuscripts containing liturgical dramas and offices which occasionally contain conducti along with a number of other accretions. Some of these include rubrics which tell us that the pieces are, in fact, conducti and allude to the purposes to which they were to be put. ${ }^{1}$ In such compilations, we can determine that the conductus was sometimes associated with or preceded readings as a kind of introduction to lessons. But there is no way of knowing whether or not this was an exclusive use, or what the other purposes might have been. Modern writers have speculated in many ways about the nature of the conductus, notably on its alleged function as a processional piece, but the genre still raises many questions. ${ }^{2}$

Given the paucity of background information, it came to me as a welcome surprise to find a relatively full account of the circumstances attending one conductus, even though its true nature is somewhat in question and though it dates from late in the history of the genre. This conductus, if it may legitimately be called that, survives in Rome, Vat. lat. 2854, an unusual manuscript dating from the end of the thirteenth, if not from the early fourteenth century. The

1 Such as London, British Library, Egerton 2515. For further examples, see the excellent article by Janet Knapp, "Conductus," The New Grove Dictionary of Music and Musicians, ed. Stanley Sadie (London: Macmillan, 1980), 4:651-52.

2 Bryan Gillingham, "A New Etiology and Etymology for the Conductus," The Musical Quarterly 75 (1991): 59-73. 
manuscript is atypical as a repository for the conductus, not only for its relatively large, near choirbook size $(315 \times 240 \mathrm{~mm}$ or about $12 \times 10$ inches $)$, but also because it is mostly non-musical. ${ }^{3}$ The manuscript, consisting of fifty-seven folios written in a uniform hand, presents a whimsical mixture of history, poetry, essays, epitaphs, prayers and two pieces of music. One is the above mentioned "conductus" in two voices; the other is a hymn. The contents of the book were likely created over a period of time and cover at least a three-year period from 1293 to 1296. A letter of sorts is described as, "metaforico non totaliter de novo inventa" (metaphorical but not totally newly-created) and bears the rubric Data Rome. xv. Kalendas Martii. millo. cc. nonagesimo tertia. $(1293)^{4}$ But there is also a rubric earlier in the manuscript (on $\mathrm{f}$. 24) which mentions the death of Benedict Gaetani II (the nephew of Boniface), which occurred in $1296 .{ }^{5}$ Pope Boniface VIII, the volume's target of adulation, reigned as Pope from 24 December 1294 to 11 October $1303 .^{6}$ The latter date is a reasonable limit for the dating of the manuscript. The anthology is a partial collection of the works of Bonaiutus de Casentino who seems to have been a better poet than musician, a man of letters, possibly some sort of physician, and at one point in his career, anxious to win a place in the circles of Boniface. ${ }^{7}$ Little is known about the man except what appears in this manuscript. We can assess his position and stature, and his purpose in putting together the anthology, in this excerpt from the opening passage:

Diversi loquium Bonaiuti [rubric] ("Diverse writings of Bonaiutus")

Collectio variorum sed non omnium opusculorum que Bonaiutus de Casentino nunc metrice nunc prosaice diversis temporibus super variis materiis scripsit. Que quidem Ego G. de Romaniola ipsius Bonaiuti scriptor sicut per diversas numeri [inveni?] petiolas ne ipsorum deperiret memoria diligenter in unum colligere procuravi.

Hic primo ponuntur versus quos de Roma composuit propter mortalitatem que fuit ibi prima estate tempore vacationis post dominum Nicolaum. VII

3 For a brief description of the manuscript, see RISM $B I V / 4,1035$.

4 On f. 35.

5 "Lamentabile carmen de morte bone memorie domini Benedicti Gaitani novelli . sancti Adriani diaconus cardinalis nepotis supradicti domini Bonifatii . pape viii . de quo inter ceteras gratias sibi divinitus attributas hec non est omittenda silentio. Nam sed florida iuventute rerumque prosperitate frondescens blanda prolixioris vite spatia crederetur. ..."

6 B. Tierney, "Boniface VIII, Pope," New Catholic Encyclopedia 2 (1967): 671.

7 Whether he was successful is not entirely clear, but he certainly seemed to be well aware of the nature of the papal circle. 
[septem] ex qua innumeri curiales qui ibi remanserant mortu sunt . preter multos qui egrotantes ad terras alias confugerunt. Dictus quidem Bonaiutus permansit ibi cum domino suo usque ad medium mensis Augusti . Postmodum victus formidine et orore infirmantum et morientium cum ipso domino suo ad civitatem Reate confugit. Qui dum egrederetur ab urbe incepit versus istos in portis . Eosque per viam prosecutus est et complevit intra menia Reatina.

[There follows a very long poem, Roma tuis gaude titulis which extends to f. 6v]

([This is] a collection of various, but not all, of the little works, sometimes metrical and sometimes prosaic, which Bonaiutus de Casentino wrote upon various subjects at different times. Of which, I, a certain G. de Romaniola, the very writer of Bonaiutus, have managed to collect diligently together in one place, so that, because of the abundance of little feet, their memory should not perish.

Here first are placed those verses composed at Rome on account of the deaths which occurred after the first summer vacation after lord Nicolaus. Seven of innumerable parishioners who remained died. Except for those who were sick many fled to other lands. Also it must be said that Bonaiutus stayed there with his lord up to the middle of August. Afterwards, having overcome fearfulness, and to pray for the infirm and dying, he fled with his lord to the city of Reate [ancient town of the Sabines]. While he was leaving the city he began these verses in the very gates. These he pursued on the trip and completed within the Reatine walls. $)^{8}$

The scribe tells us that the book is an incomplete collection of the works of Bonaiutus and proceeds to relate the circumstances surrounding the first poem in the collection. This description of attendant circumstances, a rarity in most musical manuscripts, continues as the anthology progresses.

The descriptive nature of the anthology extends to the two pieces of music which are to be found from ff. $20-22^{v}$. The first of these is the conductus $\mathrm{Hec}$ medela corporalis; the other a hymn Sanguis demptus . et retemptus written "ad laudem Bonifatii pape." This article will only be concerned with the two-voiced conductus, a transcription of which is found below. 
It first must be established that Hec medela is, in fact, a conductus, for Bonaiutus, or perhaps his scribe, refers to it as a "sequence." In the table of contents for the anthology, the sequence is entered as Notata sub duplici cantu sequentia . diei competens medicine ("A two-voiced sequence suitable for a medical appointment [medical day]") while the hymn is entered as Ymnus cum simplici cantu pro die minutiones ("A monophonic hymn for minution day"). ${ }^{10}$ The classic form of the sequence, by definition and long-standing tradition extending from the ninth to the fourteenth century, is characterized by progressive repetition of versicles in form (a) $b b c c d d \ldots x x(y)$. The form of Hec medela is $a b b a b b a b b a b b a b b a$ or perhaps $A b b a A b b a A b b a A b b a A b b a A$. In neither case is this the classic form of the sequence, although there are vestiges of the form in the repeated $b$ sections and certainly in the nature of the poetic rhyme structure (but even the latter is not entirely typical of the sequence). In the source, there is no indication whatsoever that the initial section (marked Refrain on the transcription) should be repeated between verses, but this is not an uncommon occurrence in the conductus repertoire. In this case, the music is written out once, with no demarcation between refrain and verse. Stanzas 2 to 5 are written out below the music. These extra verses do not contain enough syllables to take up all the notes; therefore, it is clear, as Wolf decided in his transcription years ago, ${ }^{11}$ that the opening section must stand alone, either as a simple prelude to the whole or as a recurrent interpolation between verses. The form of Hec medela is really strophic with refrain, a form more closely linked to the hymn than the sequence, but certainly a commonplace in the conductus repertoire. Whether or not the refrain was inserted between verses, this piece would not technically be a sequence. Johannes Wolf referred to the "rondoartigen Charakter" of the piece. ${ }^{12}$ It is clear that, with the second formal interpretation, the form is the same as the Italian ballata or the French virelai, both of which are characterized by "rondo-like" refrains. Leonard Ellinwood has suggested that the piece is an example of the conductus common in Italy around 1300 and the sort of thing that led directly to the Italian trecento secular style, ${ }^{13}$ but it seems just as likely that the influence stretched from the secular realm to the sacred, the reverse of his

10 Vat. lat. 2854, f. 1 . The significance and nature of "medical" or "minution" days is not clear from this or other sources.

11 Johannes Wolf, "Bonaiutus de Casentino, ein Dichter-Komponist um 1300," Acta Musicologica 9 (1937): 1-5.

12 Ibid., 3.

13 Leonard Ellinwood, "The Fourteenth Century in Italy," New Oxford History of Music (Oxford: Oxford University Press, 1986) 3:42-44. 
hypothesis. The rounded form above was also not unknown in the laude spirituali of thirteenth-century Italy. ${ }^{14}$

A more realistic assessment of the piece would place it as a dilettante conductus, at the least "influenced" by secular song forms, and old-fashioned for its time as the conductus had long since given way to the motet, particularly in France. The assessment of the piece as a sequence bespeaks a misunderstanding of the form, also in decline at this time, especially in Italy. The notation, which is Franconian, and the style, are at least twenty years out of date. The florid Petronian semibreve groups associated with the very late thirteenth century are lacking and the rhythmic prolongations at the ends of phrases impede the flow. It would seem to be a crude example, by one not thoroughly versed in contemporary avant-garde musical style, perhaps modelled on an earlier style imported from France, or even England, where Boniface himself had been active in his earlier years. ${ }^{15}$

But generic designation and qualitative factors are of minor interest compared to the contextual information found in the anthology and in the piece itself. We have already seen that Hec medela is suitable for medical purposes. It is equally clear that it, as well as the accompanying hymn, were directed to Pope Boniface VIII. Immediately preceding the music in the manuscript we find this account: ${ }^{16}$

Epistola mentis receptoribus se conmittens ("A statement for receptive minds is here put together")

Venerabili vel nobili viro alicui de astantibus domino nostro pape. Bonaiutus de Casentino cui terribilis est et inaccessibilis locus iste cum devota recommendatione se ipsum. In tabernaculo Dei offert unusquisque quod potest . ubi caprarum pili iuxta bissum et purpuram non vilescunt. Hoc siquidem ego fretus exemplo postquam alia non habui quibus possem perceptam de creatione novi summi pontificis demonstrare letitiam quedam de mei ingenii paupertate metra conponere ac etiam mittere nullatenus dubitavi. Sperans quid in gazophilatium cum duobus minutis vidue inter magna divitium auri et argenti pondera misceantur. Quare precor ut hec ipsi domino ad cuius honorem facta sunt cum congruum tempus et locum videritis offeratis.

14 Gustave Reese, Music in the Middle Ages (New York: W. W. Norton, 1940), 236.

15 Boniface had dealings in France and England in 1264 and 1265 long before he became Pope and continued a career characterized by many international dealings. See B. Tierney, "Boniface VIII, Pope," New Catholic Encyclopedia 2 (1967): 671 and Thomas Boase, Boniface VIII (London: Constable, 1933), passim.

16 Vat. lat. 2854 , ff. $18^{\mathrm{v}}-19$. The last brief excerpt actually follows the hymn on f. $22^{\mathrm{v}}$. 
(To some venerable or noble man close to our lord Pope, Bonaiutus de Casentino, himself in a terrible and inaccessible position, [offers himself] with devoted recommendation. One offers what one is able in the tabernacle of God, where the hairs of goats next to the throne and purple are not worthless. Since, relying on some example afterwards that I might have the percept of creation to demonstrate joy to the new high pontif, I did not hesitate to compose some poor meters [verses] of my own invention and also to send these, hoping that when the two small offerings, bereft among the great riches, when they went into the treasury, might mix with the weight of gold and silver. Because of this I pray that you might offer these to the very lord for whose honor they are made when you see an appropriate time and place.)

Magister Accursino domini pape physico Bonaiutus se ipsum. Interdum desiderat providentia dominorum aliqua etiam ludicra quibus et levius vigilie pondera portent et sompni nocui blandimenta declinent . Audivi siquidem heri quod sanctissimus pater dominus noster debeat medicinari vel minutionem hodie celebrare. In cuius honore quendam ympnium in persona cuiuslibet minuentis et quamdam sequentiam pro die medicine cum suis duplicibus. non tamen hic positis notis conponere festinavi. ut ea sibi si vestre discretioni videbitur ostendatis. Credo enim quod scribentem velut devotum laudabit velut fantasticum quod citius posset esse ridebit. Ex horum tamen altero reverentie sanctitatis sue dignitate servata. per aliquantillum temporis spatium circumvento sopore iocose forsitan sue poterit adulari vigilie.

\section{ff. 20-22 [music]}

(To Master Accursino, physician of the lord Pope, Bonaiutus himself [writes]. Meanwhile, some providence of the lords desired amusements which might help them to bear the weight of a vigil more easily and turn away the allure of harmful sleep. Indeed, I heard yesterday that the most holy father, our lord needed to celebrate the feast of medicine or ministering on this day. In whose honour a hymn in the guise of ministering and a certain sequence for medical day with its second voice I hastened to compose here in the notes given so that you might show it to him at your discretion. I believe that either he will praise the devoted writing or that he will laugh immediately at the fantasy. From these, served with the dignity of his reverent sanctity, having happily circumvented sleep for a brief space of time, he will perhaps be able to praise the vigil.)

[music] 
Doctrinale carmen conpositum ad laudem domini Bonifatii pape . viii . facientis in vita sua propriam construi sepulcuram et capellam in basilica principis apostolorum de urbe.

(The hymn composed in theory for the praise of lord Boniface VIII, having been made during his life, I have constructed near the sepulchre and chapel in the basilica of the chief apostles of the city.)

It is clear from these accounts that Bonaiutus, feeling somewhat ostracized from the Papal graces, was attempting to ingratiate himself in the higher circles. He feigned abject humility, a commonplace in this sort of preface from this time down through the centuries to Bach and beyond, likening himself to "goat hairs" while at the same time attributing luxurious features to the pontif. He seems willing to catch the attention of anyone who may find an opportunity to approach the Pope, including the Pope's physician. In the second passage he clearly attempts to appeal to a sense of amusement or entertainment to help relieve the monotony of "vigils" and perhaps to provide some element of mirth.

His statements in the preamble, as well as the content of the poetry in the conductus, suggest that he had a good sense of the nature of Pope Boniface VIII, the dedicatee of this music. Boniface was a Pope who came to power under questionable circumstances from the ranks of the Italian noble Gaetani family. His pontificate is remembered for fierce conflicts between the Church and the French monarchy which broke out in 1296. Boniface was accused of committing the papacy to novel and extravagant claims in the temporal sphere. Personally, he was reputed to be autocratic, hot-tempered, impatient, stubborn and suffered from the disease of "the stone." His bitter enemies accused him of various crimes such as heresy, simony, murder, sodomy, and worst of all, neglecting to fast on fast days. ${ }^{17}$ In this context, the substance of the poetry in Hec medela seems entirely appropriate (see translation). There is an expressed hope on the part of Bonaiutus that the piece could itself provide amusement or laughter, always a useful curative. The poem adopts an almost oxymoronic tone: on the one hand scatalogical, on the other quite lofty. The spiritual value of purging the bowels, especially for a pontif suffering from the "stone," would not go unnoticed in the papal medical establishment. The conductus itself seems almost to function as a curative, or at least analgesic, whose advice, if taken, might result in spiritual ecstasy through bodily enhancement. On another level, the piece would perhaps amuse the pontif and his circle during a vigil, so that even one who declined to observe fasts might find a vigil somewhat more attractive.

17 For more, see Tierney, "Boniface VIII, Pope," 671-73, Charles Wood, "Boniface VIII, Pope," Dictionary of the Middle Ages 2 (1983): 323-24, and Boase, Boniface VIII, passim. 


\section{Hec medela corporalis}

VI 2854, f. 20-21 v
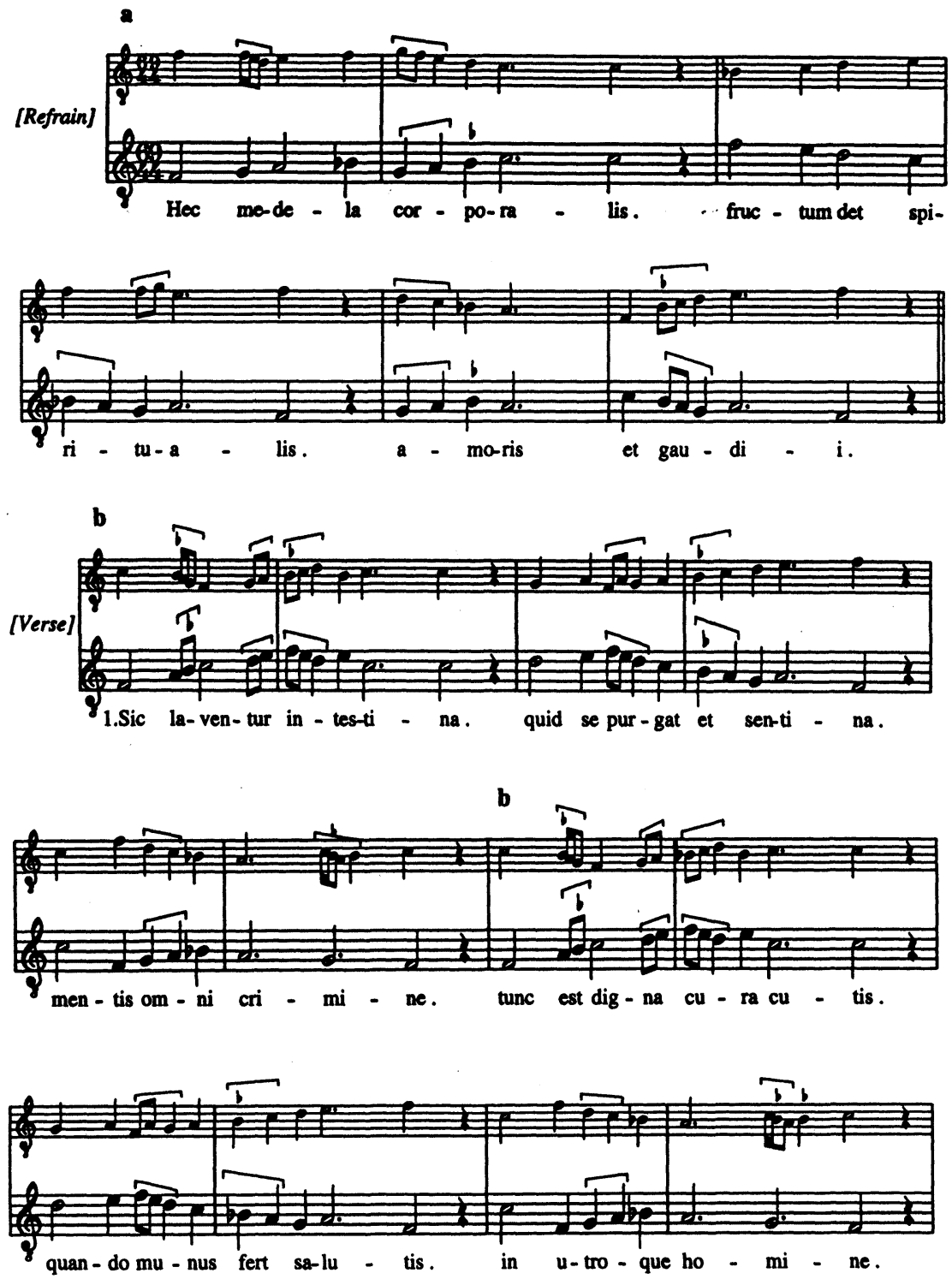

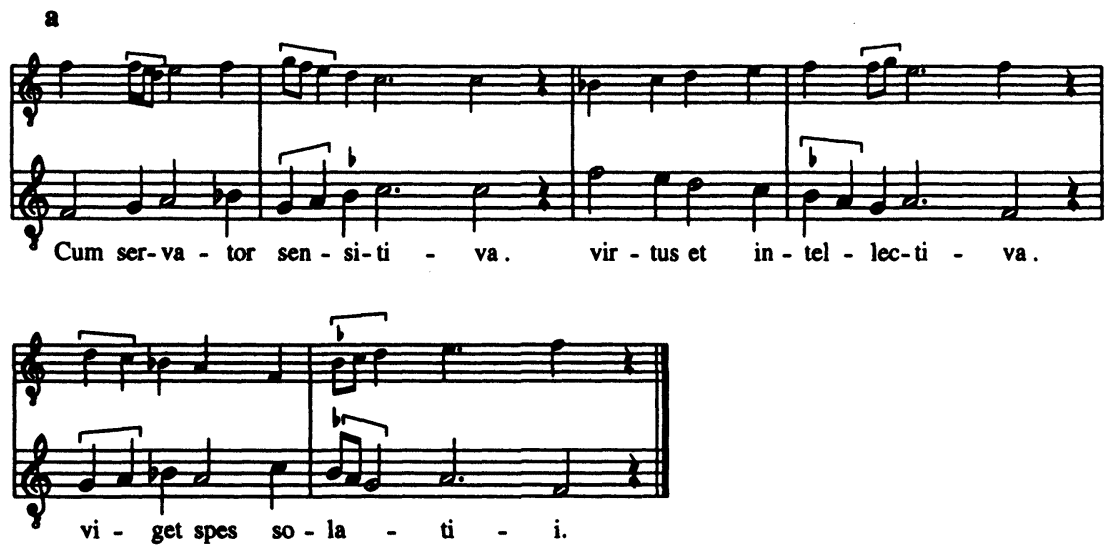

2. Sponte factus alvi fluxus . omnis stringat mentis luxus . spiritum fortificet . Cum sit omnis caro fenum . contempnenda sicut cenum . semper se vilificet .

Optet tamen sanitatem . vel conservet facultatem . divini servitii .

3. Qui membrorum spernit curam . mentem hoc ille duram. nec scit quod altissimus . Dedit opem sic vicinam. cum creavit medicinam. quam de terra carpimus . Fecit hoc ut famuletur. non ut caro dominetur . vel sit serva vitii.
4. Scimus bene quod ancilla . Si sit languens intranquilla . debilis et morbida . Nequid domine servire. presto plus est impedire . impotens et trepida.

Corpus ergo sic se servet . quod vigorem non enervet spiritalis studii .

5. Ille demum qui sanabat . dum per mundum ambulabat . corpus sensum animam . Omnis qui tunc egrotaret. et ad eum conclamaret . in vocem humilimam.

Nobis sit summa medela salus vita lux tutela . nostri desiderii . Amen.

\section{Hec medela Corporalis - Translation}

Refrain: Let this bodily remedy yield fruit of spiritual love and joy.

1. Let the bowels be so cleansed that the dregs of the mind are cleansed of every $\sin$. Then is care of the skin worthy since it bears the gift of salvation in both parts of the man. When the observer is sensitive, virtuous and perceptive, hope of solace flourishes.

2. Having made the belly flow freely let the luxury of every mind draw together, let the spirit fortify! When all flesh is as hay, despised just as filth, it always esteems itself of little value. Let it choose sanity or conserve the faculty of divine service. 
3. He who spurns the care of the members, hardened in his mind, will never know the highest. He who gives up the related task, when he created medicine which we pluck from the earth, did this in order to serve, not to be overwhelmed by the flesh or to be the slave of sin.

4. We know well that the handmaid, if she be languishing in upset, is weak and morbid. Being unable to serve the master is preferable to impeding him, impotent and trembling. The body thus must serve itself, that the strength for spiritual study is not weakened.

5. Finally, he who was healthy while walking through the world would be a body aware of the mind. Everyone who then would be sick, in a humble voice to him would shout. For us let there be a high remedy, let there be a safe life, and a guarding of the light of our desires. Amen.

What are the broader ramifications of this little conductus and the context associated with it? We cannot, of course, say that the conductus was always used in a palliative sense; indeed, almost all of them were not written in that spirit at all. Nor can we assume that such pieces were always used to gain personal aggrandizement. The majority of works, in view of the overwhelming anonymity which surrounds their presentation and transmission, were demonstrably selfeffacing. But it does point out that in the hierarchical nature of medieval society, where secular and ecclesiastical nobility and class structure blended, it helped to approach those at the pinnacle in order to achieve success. Hec medela itself, with its poetic and formal links to the secular world and its dated musical style, cannot really be cast as an influential monument. But it does confirm that such a piece could be used in other than liturgical circumstances by the most eminent figures in the church for purposes other than those "processional" ones which have so long dogged the history of the genre. In this case, we are fortunate to have a relatively full documentation of the possibility, even if it is troublesome to extend this any further.

\section{Abstract}

One of the difficulties in creating an adequate picture of the contextual situation for music, other than that clearly associated with the liturgy, in the Middle Ages, is the paucity of accounts describing performance circumstances. We know little about the social milieu and purposes attending genres marginal to the liturgy such as the conductus and thirteenth-century motet. A manuscript which seems to redress this problem, albeit for one very specific instance, is Vat. lat. 2854 in the Vatican library in Rome.

This manuscript is unusual in that it contains not only music but a detailed account of why the music was written. The author, Bonaiutus de Casentino, active in the circle of 
Pope Boniface VIII, prepared the manuscript in the last decade of the thirteenth century at Rome. The document includes various poems, sacred and secular, as well as two Latin songs written in late Franconian notation. One of the pieces is a two-voice conductus ( $\mathrm{Hec}$ medela corporalis) which was written, according to the account of Bonaiutus himself, in order to cure the maladies of an ailing pontif. The pontifical complaints seemed to be both psychological and intestinal in nature. It was the hope of Bonaiutus not only to provoke laughter (always a curative), but also to cleanse the papal bowels through his composition. Although one cannot generalize on the basis of this single incident, it does yield a fascinating glimpse into a possible venue for the conductus. 